\title{
PENERAPAN METODE THINK-TALK-WRITE UNTUK MENGEMBANGKAN SELF CONFIDENCE SISWA SD
}

\author{
Sri Winggowati \\ SDN 023 Pajagalan \\ sriwonggo72@gmail.com
}

\begin{abstract}
ABSTRAK
Penelitian ini dilatarbelakangi permasalahan banyak siswa SD yang kesulitan menyelesaikan soal matematika terutama yang berhubungan dengan self confidence siswa. Tujuan penelitian ini adalah untuk menjawab pertanyaan apakah dengan Metode Think-Talk-Write (TTW) dapat mengembangkan self confidence siswa. Metode penelitian yang digunakan yaitu, Penelitian Tindakan Kelas, yang terdiri dari 3 siklus pembelajaran, masing-masing siklus terdiri dari 3 tindakan. Populasi dalam penelitan ini adalah siswa kelas VI SD di Kota Bandung. Instrumen yang digunakan meliputi berupa pedoman observasi, wawancara, angket dan dokumentasi. Data kuantitatif yang diperoleh dianalisis dengan menggunakan SPSS 19, sedangkan data kualitatif menggunakan teknik Miles \& Huberman. Hasil penelitian menunjukkan bahwa terdapat peningkatan self confidence siswa dengan pembelajaran Metode Think-Talk-Write (TTW). Rekomendasi dalam penelitian ini menekankan pembelajaran Metode Think-Talk-Write (TTW) sebagai salah satu alternatif metode pembelajaran yang mampu memberikan manfaat dan stimulasi yang baik terhadap kepercayaan diri siswa Sekolah Dasar dalam pembelajaran matematika sesuai dengan tahapan perkembangan kognitif siswa.
\end{abstract}

Kata Kunci: self confidence siswa, metode TTW (Think-Talk-Write).

\begin{abstract}
This research is based on the problems of many elementary students who have difficulty solving math problems especially those related to students' mathematical communication ability. The purpose of this study is to answer the question whether by Think-Talk-Write method (TTW) can develop student self confidence. The research method used is Classroom Action Research, which consists of 3 learning cycles, each cycle consists of 3 actions. Population in this research is grade 6 student of SD in Bandung City. The instruments used include students' mathematical communication skills such as stories, questionnaires, observation guidelines, interviews and documentation. The quantitative data obtained were analyzed using SPSS 19, while the qualitative data used Miles \& Huberman technique. The results showed that there is an increase in selfconfidence of students with learning Think-Talk-Write method (TTW). The recommendation in this research emphasizes the learning of Think-Talk-Write method (TTW) as one of the alternative learning method that able to give good benefit and stimulation to the ability and confidence of elementary school students in mathematics learning in accordance with the stages of cognitive development of students.
\end{abstract}

Keywords: self confidence student, TTW Method (Think-Talk-Write). 


\section{PENDAHULUAN}

Kepercayaan diri atau self confidence siswa dewasa ini diharapkan muncul dan berkembang sebagai hasil penerapan model dan metode pembelajaran pada mata pelajaran matematika. Self Confidence siswa dapat diukur dari cara bagaimana siswa mengekspresikan dan mengemukakan kembali apa yang didapatnya sebagai hasil belajar matematika terutama pada penyelesaian soal cerita pada materi perbandingan dan skala. Menurut Lestari, Yudhanegara (2015:95) "Self Confidence adalah suatu sikap yakin akan kemampuan diri sendiri dan memandang diri sendiri sebagai pribadi yang utuh dengan mengacu konsep diri”. Self confidence dimiliki oleh semua siswa, dalam hal ini guru berperan memupuk dan mengembangkan potensi tersebut dengan penerapan berbagai macam model dan metode pembelajaran.

Proses pembelajaran karena mengutamakan keaktifan guru mengakibatkan lemahnya hasil belajar siswa dari aspek aktifitas dan berimbas pada prestasi dan penerapan hasil belajar dalam kehidupan sehari-hari, saat siswa hanya menjadi pendengar pasif akan berakibat siswa tidak mendapat pengalaman langsung dalam pembelajaran. Proses pembelajaran kurang bermakna karena kurangnya penerapan konten masalah nyata dalam soal cerita/ kalimat matematika. Di dalam permendikbud no 22 tahun 2016 tentang standar proses di dalam lampirannya, Depdikbud (2016:4), "Pembelajaran sepenuhnya diarahkan pada pengembangan ketiga ranah secara utuh/holistik, artinya pengembangan ranah yang satu tidak bisa dipisahkan dengan ranah lainnya". Self Confidence bagian dari ranah yang diharapkan terintegrasi utuh dalam diri siswa. Dengan demikian proses pembelajaran secara utuh melahirkan kualitas pribadi yang sikap, pengetahuan, dan keterampilan. Hal tersebut berakibat siswa tidak mampu mengimitasi aktifitas dan menumbuhkan kepercayaan diri.

Guru sebagai unsur penting yang berperan sebagai fasilitator akan memberi warna pada proses pembelajaran yang bermakna dan pengalaman yang akan diidentifikasi siswa untuk mengembangkan kepercayaan dirinya, bagaimana bisa siswa mengenmbangkan self confidence dirinya jika sedikit mendapat pengalaman ekspresi diri sebagai latihan keseharian. Kegiatan pembelajaran yang dilaksanakan masih didominasi oleh guru dengan metode ceramah dan menuliskan di papan tulis latihan soal untuk siswa yang merupakan cara mudah, cepat dan sederhana yang tidak memerlukan persiapan banyak alat. Lemahnya proses pembelajaran karena mengutamakan keaktifan guru, sementara siswa menjadi pendengar pasif, berakibat pula terhadap rendahnya self confidence siswa. 
Kemampuan dan ketelitian guru menggunakan model pembelajaran yang membuat siswa aktif, kreatif belajar sangat diperlukan. Penggunaan model pembelajaran yang membelajarkan siswa dengan melalui tahap-tahap bermakna memang memerlukan alokasi waktu dan sarana prasarana yang menunjang. Sehingga hal tersebut seringkali menjadi kendala yang akhirnya guru melakukan proses pembelajaran secara langsung karena menyesuaikan dengan situasi dan kondisi di sekolah dan kelasnya.

Kurikulum 2013 kini memberi keleluasaan dalam penggunaan model dan metode pembelajaran. Salah satu metode yang dapat digunakan untuk mengembangkan self confidence siswa adalah metode Think-Talk-Write (TTW). Metode pembelajaran ini bukan merupakan model yang khusus dibuat untuk mata pelajaran matematika, akan tetapi karena dewasa ini matematika bukan hanya sekedar angka dan nomor maka aplikasi metode lain pada mata pelajaran matematika patut dilakukan sebagai upaya membantu mengembangkan self confidence siswa terutama saat menyampaikan ide -ide matematika yang telah didapatnya. Pada kurikulum 2013 ini mata pelajaran dipaksakan untuk masuk mengikuti alur tematik, akan tetapi memiliki keunggulan sehingga konten matematika disajikan secara kontekstual yang dekat dengan masalah dan lingkungan siswa. Kesulitan lain adalah pada saat matematika tidak disampaikan mengikuti hirarki dari yang mudah menuju ke yang sukar, dan dari konsep konkrit menuju ke abstrak.

Penggunaan Metode $T T W$ dalam pembelajaran matematika disajikan dengan menyodorkan berbagai masalah yang erat kaitannya dengan kehidupan siswa. Karena fokus masalah antara lain pada materi penyelesaian soal cerita dan merangsang siswa untuk mampu berkomunikasi sebagai bentuk ekspresi kepercayaan dirinya maka pembelajaran dilaksanakan dengan metode yang menggali dan memancing siswa berkomunikasi dan mengembangkan self confidence siswa yaitu Metode $T T W$.

Berdasarkan kenyataan diatas kiranya bisa disampaikan bahwa permasalahan mengenai kesulitan siswa terhadap materi matematika, khususnya pada penyelesaian soal cerita matematika materi skala dan perbandingan mengakibatkan rendahnya self confidence siswa. Rendahnya kemampuan penyelesaian soal cerita akan dapat diatasi dengan meningkatkan kemampuan guru mengeksplorasi kemampuannya mengelola kelas, menentukan model, strategi dan teknik pembelajaran yang tepat.

Penelitian ini dimaksudkan untuk mengidentifikasi dan mendeskripsikan hal-hal yang berkaitan dengan penerapan Metode $T T W$ dalam mengembangkan self confidence siswa pada materi perbandingan dan skala di kelas 6 SDPN Pajagalan 58 Bandung . 
$\overline{\text { Adapun tujuan penelitian adalah untuk mengetahui apakah Metode } T T W \text { dalam soal cerita }}$ pada materi perbandingan dan skala dapat mengembangkan self confidence siswa dan untuk mengetahui bagaimana self confidence siswa dalam aktivitas pembelajaran yang menerapkan Metode $T T W$.

Penerapan Metode TTW diharapkan menjadi obat yang tepat untuk mengatasi permasalahan yang dihadapi khususnya pada materi skala dan perbandingan. Selain itu dengan penelitian ini mengembangkan self confidence siswa. Berdasarkan data di atas perlu dilaksanakan penelitian tindakan kelas sebagai usaha untuk mengembangkan self confidence siswa khususnya materi perbandingan dan skala di kelas 6 SDPN Pajagalan 58.

\section{METODE PENELITIAN}

Penelitian menggunakan Classroom Action Research atau Penelitian Tindakan Kelas. Prosedur penelitian tindakan kelas yang digunakan dalam penelitian ini adalah model spiral dari Kemmis \& Mc Taggart dalam Arikunto (2016: 42) PTK dilaksanakan melalui proses pengkajian berdaur yang terdiri dari 4 tahap, yaitu perencanaan (planning), pelaksanaan tindakan (action), observasi (observation), dan refleksi (reflection). Model spiral ini merupakan model siklus berulang berkelanjutan, dengan harapan pada setiap tindakan menunjukkan peningkatan sesuai perubahan dan perbaikan yang ingin dicapai.

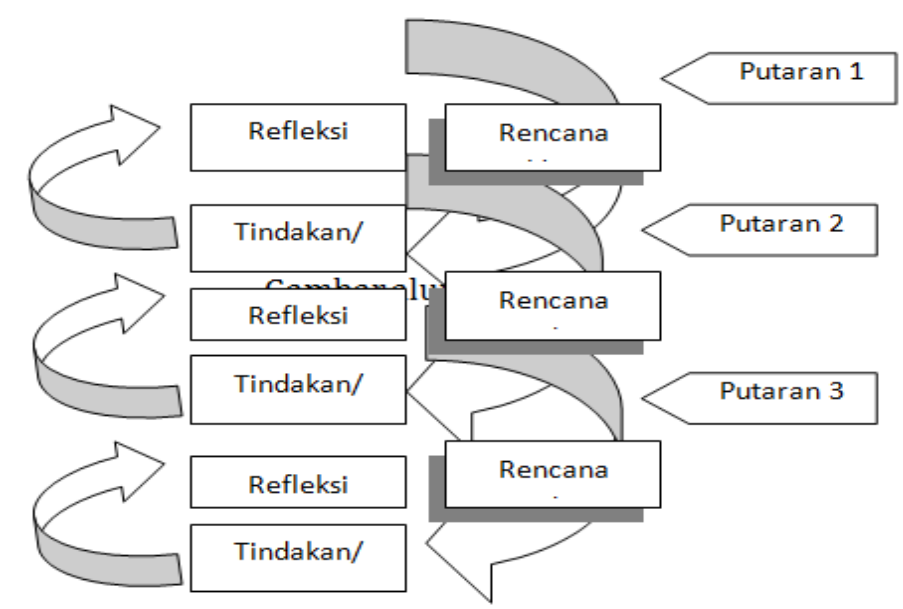

Gambar 1. Diagram Siklus Kemmis \& Mc.Taggart

Secara singkat, Penelitian Tindakan Kelas adalah penelitian yang dilakukan guru atau praktisi yang memiliki tujuan memperbaiki pembelajaran di kelas serta meningkatkan mutu pembelajaran di kelas. Mutu pembelajaran dapat dilihat dari meningkatnya self confidence siswa. Masalah utama dalam penelitian ini adalah bagaimana mengembangkan self confidence siswa dengan menerapkan pembelajaran Metode TTW pada materi skala dan perbandingan. Penelitian ini diharapkan selain dapat mengembangkan profesionalisme 
guru SD dalam meningkatkan kualitas pembelajaran matematika, serta mampu menjalin kemitraan antara peneliti dengan guru lainnya dalam memecahkan masalah yang terjadi dalam proses kegiatan belajar mengajar matematika di kelas.

Penelitian dilaksanakan di SDPN Pajagalan 58 Bandung, Jalan Pajagalan nomor 58 Kelurahan Karanganyar Kecamatan Astanaanyar Kota Bandung. Waktu Penelitian dilaksanakan pada bulan Maret hingga bulan April 2017. Dalam penelitian ini yang menjadi subjek penelitian adalah kelas 6 SDPN Pajagalan 58 Bandung Tahun Pelajaran 2016-2017. Instrumen data penelitian yang digunakan meliputi instrument kualitatif dan kuantitatif, instrument data kualittatif yang digunakan antara lain angket yang digunakan dalam penelitian adalah angket self confidence. Angket tersebut digunakan untuk mengetahui keyakinan kemampuan diri, optimis, objektif, bertanggung jawab, serta rasional dan realistic. Angket self confidence yang digunakan dalam pembelajaran menggunakan skala sikap Likert.

Aspek penilaian Skala self confidence dalam penelitian ini berdasarkan pada 5 aspek pengukuran yaitu, keyakinan kemampuan diri, optimis, objektif, bertanggung jawab, serta rasional dan realistik. Adapun indikator pengukuran self confidence ditunjukkan pada tabel di bawah ini.

Tabel 2. Indikator Self Confidence

\begin{tabular}{|c|c|c|}
\hline No & Aspek & Indikator \\
\hline 1 & $\begin{array}{l}\text { keyakinan kemampuan } \\
\text { diri }\end{array}$ & $\begin{array}{l}\text { Kemampuan siswa untuk menyelesaikan sesuatu dengan sungguh- } \\
\text { sungguh }\end{array}$ \\
\hline 2 & Optimis & $\begin{array}{l}\text { Sikap dan perilaku siswa yang selalu berpandangan baik tenang dirinya } \\
\text { dan kemampuannya }\end{array}$ \\
\hline 3 & Objektif & Kemampuan siswa menyelesaikan permasalahan sesuai dengan fakta \\
\hline 4 & Bertanggung jawab & $\begin{array}{l}\text { Kemampuan siswa untuk berani menanggung segala sesuatu yang telah } \\
\text { menjadi konsekuensinya }\end{array}$ \\
\hline 5 & Rasional dan realistic & $\begin{array}{l}\text { Kemampuan siswa untuk menganalisis suatu masalah dengan logis dan } \\
\text { sesuai dengan kenyataan. }\end{array}$ \\
\hline
\end{tabular}

Diadaptasi dari Lauster (Ghufron \& Rini, 2011)

Proses perhitungannya menggunakan software Microsoft excel 2010, Azwar (2012:143), menyatakan bahwa prosedur perhitungan skor skala self confidence setiap nomor yaitu, (1) Menghitung frekuensi masing-masing kategori tiap butir pernyataan; (2) Menentukan proporsi masing-masing kategori; (3) Menghitung besarnya proporsi kumulatif; (4) Menghitung nilai dari $\mathrm{pk}_{\text {tengah }}=1 / 2 \mathrm{p}+\mathrm{pkb}$, dimana $\mathrm{pkb}=$ proporsi kumulatif dalam kategori sebelah kiri; (5) Mencari dalam tabel distribusi normal standar 
bilangan baku (Z) yang sesuai dengan pk tengah; (6) Menjumlahkan niai $\mathrm{Z}$ dengan suatu konstansta $\mathrm{k}$ sehingga diperoleh nilai terkecil dari $\mathrm{z}+\mathrm{k}=1$ untuk suatu kategori pada satu pernyataan; dan (7) Membulatkan hasil penjumlahan pada langkah 6.

Skor untuk kategori SS,S,N,TS, dan STS setiap pernyataan bervariasi dari 1 sampai dengan 5 dengan skor total ideal 95. Wawancara digunakan untuk memperoleh data kualitatif atau pendapat mengenai pembelajaran yang terjadi di kelas. Objek wawancara adalah siswa dan pengamat, yang berasal dari guru juga sebagai mitra penelitian. Pelaksanaan wawancara dilakukan secara bebas maupun terstruktur. Obsevarsi yang dilakukan pengamat adalah melihat kegiatan belajar mengajar guru dan siswa pembelajaran matematika dalam menerapkan Metode $T T W$. Lembar obeservasi terbuka harus diisi oleh pengamat secara naratif pada kolom deskripsi yang sesuai dengan item pertanyaan dan pernyataan.

Tahap-tahap Model Mixed Methode yang dilakukan dalam penelitian : (Diadaptasi dari Indrawan dan Yaniawati, 2014). Yaitu identifikasi masalah, penyusunan instrument dan bahan ajar, uji coba instrument, analisis hasil uji coba, perbaikan instrument, pretest, pembelajaran model PTK, angket, wawancara self confidenc, postes, analisis hasil data, kesimpulan dan saran. Pengumpulan Data, tahap awal penulis mengumpulkan data lapangan berupa hasil observasi terkait dengan pelaksanaan Metode TTW dalam mengembangkan self confidence siswa.

Tahap berikutnya adalah proses menyeleksi, menentukan fokus, menyederhanakan, meringkas dan mengubah bentuk data mentah yang diperoleh di lapangan. Reduksi data dimulai dari pembuatan rangkuman dari setiap data yang bertujuan agar mudah dimengerti. Adapun reduksi data dalam penelitian ini yaitu keseluruhan rangkuman data yang berupa hasil observasi mengenai pelaksanaan pembelajaran dengan Metode TTW.

Display Data, beberapa macam data lapangan yang telah direduksi perlu ditampilkan dan dideskripsikan. Data yang telah direduksi sebelumnya disajikan dalam bentuk deskripsi dan dokumentasi. Adapun display data dalam penelitian ini yaitu deskripsi pelaksanaan pembelajaran model problem based learning secara naratif yang disertai dengan penampilan gambar pelaksanaan pembelajaran tersebut.

\section{HASIL DAN PEMBAHASAN}

Analisis hasil penelitian siswa diamati dalam perkembangan self confidence pada setiap siklus pembelajaran dengan Metode $T T W$. Diketahui pada pembelajaran siklus I dengan Metode ini ada kecenderungan perkembangan self confidence siswa dalam 
interaksi belajar mengajarnya. Dari pengamatan diketahui self confidence siswa sebelum dilakukannya pembelajaran Metode $T T W$ berada pada keadaan pembelajaran yang pasif. Kemudian setelah diberi perlakuan pembelajaran dengan Metode TTW ternyata mengalami peningkatan kepercayaan diri dalam proses dan interaksi pembelajaran. Demikian pula bila dilihat dari hasil pengamatan setiap siklus hingga akhir siklus mengalami kecenderungan perkembangan self confidence siswa yang cukup baik.

Hal ini disebabkan karena dalam pembelajaran menggunakan metode TTW siswa diberikan masalah kontekstual yang dekat dengan permasalahan dalam kehidupan sehariharinya, sebelum mereka menemukan konsep. Masalah yang dihadapi dipecahkan bersama dalam kegiatan belajar berkelompok dengan menggunakan, langkah awal dari metode ini adalah Think, yang berarti siswa harus berfikir untuk menemukan cara menyelesaikan masalah yang dihadapinya. Penggunaan Metode $T T W$ sejauh ini efektif meningkatkan self confidence siswa. Metode ini mendorong siswa untuk berani berbicara dan mengungkapkan ide dan gagasan matematikanya baik secara lisan maupun tertulis. Hasil yang diperoleh dari penelitian menunjukkan dalam proses belajar siswa terlihat mampu berdiskusi dengan lancar dan lebih ramai dari biasanya. Lembar kerja siswa mampu memancing siswa bereaksi dan berbicara untuk mendiskusikan soal yang harus mereka selesaikan.

Menurut hasil data kualitatif yang diperoleh dari wawancara menunjukkan bahwa self confidence siswa meningkat setelah mendapatkan Metode TTW. Siswa mengatakan bahwa soal-soal lebih mudah difahami karena menggunakan lembar kerja siswa sebagai bagian dari teknis Metode $T T W$. Siswa mampu menjawab soal dengan mudah karena sebelumnya telah terjadi interaksi dengan siswa lain di dalam kelompok, belajar di dalam kelompok membuat mereka bebas bertanya, saling mengingatkan, saling membantu kemudian pengetahuan mereka akan dikuatkan dengan penjelasan guru sehingga membuat self confidence mereka berkembang. Metode TTW merupakan metode yang memfasilitasi berkembangnya self confidence siswa, dapat dilihat dari pengertian Think-Talk-Write menurut Huda (2015: 218) yaitu strategi yang memfasilitasi latihan berbahasa secara lisan dan menulis bahasa tersebut dengan lancar. Sehingga bukan merupakan suatu kebetulan jika self confidence meningkat dengan Metode $T T W$ karena kemampuan berbahasa yang meningkat dan berarti menunjang self confidence siswa.

Gambaran aktivitas siswa dengan Metode $T T W$ : pada umumnya, antusiasme mengikuti pembelajaran sangat baik, karena siswa mendapat skenario yang berbeda 
dibandingkan dengan pembelajaran langsung. Beberapa siswa mampu mengajukan dan menjawab pertanyaan secara kritis. Pembelajaran aktif perlu dirancang agar aktivitas siswa meningkat, secara sederhana pembelajaran aktif didefinisikan sebagai metode pengajaran yang melibatkan siswa secara aktif dalam proses pembelajaran. Berdasarkan pengamatan terhadap siswa dengan indikator dapat disampaikan bahwa sebagian besar siswa mengikuti kegiatan dalam kategori baik, sebagian kecil sangat baik dan sisanya cukup, hampir tidak ada aktivitas siswa dalam kategori tidak nampak.

Kepercayaan diri dalam Ghufron \& Rini (2011:35), berpendapat "kepercayaan diri adalah salah satu aspek kepribadian yang penting pada seseorang, tanpa adanya kepercayaan diri akan banyak menimbulkan masalah pada diri seseorang”. Pendapat ahli ini ditunjukkan hasil angket self confidence sebagian besar siswa yang mengatakan bahwa mereka percaya diri ketika akan menghadapi tes yang diberikan oleh guru, mereka memiliki keyakinan mampu menjawab pertanyaan-pertanyaan, berani dan percaya diri untuk mengajukan pertanyaan. Siswa mampu mengukur kemampuan dirinya menyelesaikan masalah yang disajikan dalam soal cerita karena telah terbiasa diberikan latihan menghadapi dan menyelesaikan soal-soal tersebut. Pada umumnya siswa tidak takut salah lagi, tidak terkendala oleh tuntutan nilai yang tinggi, tidak merasa takut apabila tidak mampu menjawab soal dengan benar, karena situasi kelas dengan Metode TTW dikondisikan santai, tidak tegang, hiruk pikuk namun tenang mengakomodasi tahapan dan langkah dalam proses belajar mengajar.

\section{KESIMPULAN}

Berdasarkan analisis data, temuan dan hasil penelitian, diperoleh kesimpulan bahwa self confidence siswa dengan Metode TTW signifikan. Serta meningkatnya aktivitas siswa dalam pembelajaran Metode $T T W$. Berdasarkan kesimpulan dari hasil penelitian di atas diperoleh bahwa penggunaan pembelajaran Metode TTW berhasil membuat siswa mengembangkan self confidence siswa secara signifikan. Kesimpulan tersebut memberikan implikasi bahwa Metode TTW dapat dijadikan sebagai alternatif metode pembelajaran yang dapat mengembangkan self confidence siswa di tingkat Sekolah Dasar. Pembelajaran Metode $T T W$ lebih menekankan pada proses bagaimana cara siswa berbahasa dan berinteraksi memecahkan masalah serta dapat mengkomunikasikannya. Pembelajaran dengan Metode TTW dapat meningkatkan self confidence siswa Sekolah Dasar untuk merefleksikan suatu permasalahan, mengekspresikan pemikiran, ide-ide, pendapat, atau gagasannya sebagai respon terhadap situasi atau permasalahan matematis yang diberikan. 
Pembelajaran Metode $T T W$ dengan cara belajar kelompok dapat menjalin kerja sama dan komunikasi yang aktif, melatih melatih keberanian, dan belajar menghargai potensi yang dimilikinya sehingga tercipta atmosfir belajar yang kondusif dan menyenangkan.

Berdasarkan kesimpulan dan implikasi dari penelitian ini, selanjutnya akan dikemukakan beberapa rekomendasi yang dapat diberikan, di antaranya, Metode TTW hendaknya diaplikasikan oleh guru, terutama pada jenjang Sekolah Dasar dalam proses pembelajaran di dalam kelas untuk mengembangkan self confidence siswa. Dalam pembelajaran Metode $T T W$ situasi atau masalah matematis yang disajikan dalam Lembar Kerja Siswa (LKS) menjadi fokus kegiatan siswa dalam belajar kelompok, sehingga dapat mendorong siswa untuk berperan aktif dalam proses pembelajaran. Dalam proses pembelajaran Metode $T T W$, keterbatasan waktu adalah salah satu kendala yang dihadapi. Dengan demikian, untuk mengatasinya, siswa dapat mempelajari permasalahanpermasalahan yang ada di dalam Lembar Kerja Siswa (LKS) secara individu terlebih dahulu sebelumnya.

Kemampuan dan kecepatan siswa dalam belajar relatif berbeda-beda. Untuk mengatasinya, dapat dilakukan dengan cara tutor sebaya, yaitu siswa yang pandai membantu siswa lainnya yang masih kurang. Kepada peneliti lain yang tertarik untuk menerapkan pembelajaran Metode $T T W$ dengan tujuan untuk mengembangkan self confidence siswa, agar menerapkannya pada objek dan level yang berbeda. Hal tersebut dimaksudkan agar diperoleh temuan-temuan berbeda dan saling melengkapi pada saat penelitian di lapangan. Saran untuk penelitian berikutnya, agar dapat mengkaji pengembangan diri lainnya, yang dimungkinkan dapat meningkat dengan menggunakan Metode TTW. Pengembangan diri yang lain misalnya self efficacy, kemampuan tersebut dapat dilatih dan ditingkatkan dengan tahapan-tahapan Metode TTW.

Penulis menyampaikan rasa terima kasih yang sebesar-besarnya dan penghargaan yang setinggi-tingginya kepada Kepala Sekolah SDPN Pajagalan 58 dan rekan-rekan guru yang telah memberikan dorongan, petunjuk, saran dan arahan hingga dapat diselesaikannya penelitian ini, meskipun dengan segala kekurangannya.

\section{REFERENSI}

Hapsari S. Pd. \& Mahrita, K. (2011) Upaya Meningkatkan Self-Confidence Siswa Dalam Pembelajaran Matematika Melalui Model Inkuiri Terbimbing, Prosiding ISBN : $978-979-16353-6-3$, Uny

Indrawan \& Yaniawati, (2014) Metodologi Penelitian, Bandung; PT. Refika Aditama. 
Knisley, J. (2003) A Four-Stage Model of Mathematical Learning. Dalam Mathematics Educator. (Online), vol.12 (1), 10 halaman. Tersedia: http://math.coe.uga.edu/TME/issues/v.12n1/v12n1.Knisley.pdf. (7 April 2015)

Komara, B.I. (2016) Hubungan antara Kepercayaan Diri dengan Prestasi Belajar dan Perencanaan Karir Siswa. Jurnal Pdikopedagogia Universitas Ahmad Dahlan, Vol. 5 No. 1, 2016 ISSN: 2301-6167

Majid, A. (2014) Implementasi Kurikulum 2013, Bandung ; Interes Media. 